\title{
Optimalisasi pembelajaran self-study pada program Paket A di pusat kegiatan belajar masyarakat di masa pandemi
}

\author{
Edhy Rustan *, Baderia Baderia, Rahmat Tamrin \\ Institut Agama Islam Negeri (IAIN) Palopo. Jl. Agatis Balandai Kota Palopo, 91914 Indonesia \\ * Corresponding author email: edhy_rustan@iainpalopo.ac.id
}

Received: 15 October 2020; Revised: 2 November 2020; Accepted: 9 November 2020

\begin{abstract}
Abstrak: Pandemi COVID-19 mensyaratkan social distance, sehingga pembelajaran mandiri perlu dimaksimalkan. Tujuan penelitian ini adalah untuk memaparkan (1) bentuk pembelajaran self-study, (2) kendala, dan (3) manfaat pembelajaran self-study pada program paket A di PKBM Rantenase selama pandemic COVID-19. Penelitian ini merupakan penelitian deskriptif kualitatif. Subjek penelitian ini adalah pengelola, tutor, dan warga belajar program paket A. Metode pengumpulan data menggunakan wawancara, observasi, dan dokumentasi. Data yang diperoleh kemudian dianalisis interaktif dengan cara reduksi, penyajian, dan penarikan kesimpulan. Hasil penelitian menunjukkan bahwa pembelajaran mandiri di PKBM Rantenase dilaksanakan dengan tutor mengarahkan peserta didik melalui pesan SMS maupun Whatsapp sedangkan evaluasi diganti dengan penugasan. Kendala yang ditemui selama pembelajaran di masa pandemic yakni kendala teknis seperti akses jaringan, ketersediaan sarana dan prasarana serta sumber belajar. Sedangkan kendala nonteknis yakni karakteristik warga belajar. Manfaat pembelajaran self-study memperkuat literasi fungsional terutama keterampilan literasi digital, membangkitkan semangat penggerak pemberdayaan masyarakat terutama dalam pembelajaran meski dengan segala keterbatasan. Peserta didik memperoleh pengalaman belajar yang bermakna, berdasarkan potensi dan kebutuhannya.
\end{abstract}

Kata Kunci: pembelajaran self-study, program paket A, PKBM

\section{Optimization of self-study learning in the Paket A program at the community learning activity center during the pandemic}

\begin{abstract}
The COVID-19 pandemic requires social distance, so independent learning needs to be maximized. The purpose of this study was to describe (1) the form of self-study learning, (2) constraints, and (3) the benefits of self-study learning in the package A program in PKBM Rantenase during the COVID-19 pandemic. This research is a qualitative descriptive study. The subjects of this study were managers, tutors, and learning citizens of the package A program. Data collection methods used interviews, observation, and documentation. The data obtained were then analyzed interactively by means of reduction, presentation, and drawing conclusions. The results showed that independent learning in PKBM Rantenase was carried out with a tutor directing students via SMS or Whatsapp messages while assignments replaced evaluation. The obstacles encountered during learning during the pandemic were technical problems such as network access, the availability of facilities and infrastructure, and learning resources. Meanwhile, non-technical constraints are the characteristics of the learning community. The benefits of self-study learning strengthen functional literacy, especially digital literacy skills, arouse the spirit of community empowerment, especially in learning even with all the limitations. Learners gain meaningful learning experiences based on their potential and needs.
\end{abstract}

Keywords: self-study learning, package A program, PKBM

How to Cite: Rustan, E., Baderia, B., \& Tamrin, R. (2020). Optimalisasi pembelajaran self-study pada program Paket A di pusat kegiatan belajar masyarakat di masa pandemi.JPPM (Jurnal Pendidikan dan Pemberdayaan Masyarakat), 7(2), 180-189. doi:https://doi.org/10.21831/jppm.v7i2.35097 


\section{JPPM (Jurnal Pendidikan dan Pemberdayaan Masyarakat), 7 (2), 2020 - 181}

Edhy Rustan, Baderia Baderia, Rahmat Tamrin

\section{PENDAHULUAN}

Permasalahan putus sekolah yang dihadapi masyarakat Rantenase Kelurahan Peta, menjadikan PKBM sebagai alternatif solusi. Hal lain yang memengaruhi pembelajaran pada PKBM yaitu faktor geografis. Daerah pegunungan menjadikan akses pendidikan menjadi susah terjangkau oleh semua warga belajar. Generasi muda menjadi petani untuk membantu pemenuhan perekonomian keluarga.

Pendidikan program paket A dalam pelaksanaannya didesain dengan konsep pembelajaran mandiri. Mandiri dapat diartikan sebagai belajar secara individual agar mampu menguasai keahlian tertentu. Hal terpenting dalam proses pembelajaran mandiri adalah peserta didik memiliki kemampuan dan keterampilan dalam proses pembelajaran tanpa bantuan tutor maupun orang lain (R. A. Putra et al., 2017). Tujuan pola pembelajaran mandiri diharapkan untuk memberikan kesempatan dan keleluasan kepada peserta didik untuk belajar berdasarkan kemampuan (kompetensi) sendiri serta pengembangan kemampuan tiap individu (A. Fauzi et al., 2019). Secara mandiri pebelajar dituntut bertanggung jawab kepada diri sendiri. Pembelajar dapat melatih diri dengan cara mengenali kekurangan yang dimiliki dan mencoba mencari cara untuk memperbaiki kekurangan tersebut.

Pembelajaran mandiri mengacu pada model pembelajaran dimana pebelajar belajar sesuai dengan kemampuan dan kesempatan masing-masing (A. Fauzi et al., 2019). Dalam pembelajaran mandiri, pebelajar secara mandiri mempunyai kebebasan untuk belajar tanpa harus menghadiri pembelajaran di kelas secara langsung oleh guru (Meliansari et al., 2017). Pembelajar lebih fleksibel mengatur waktu untuk belajar, dapat menentukan sendiri kapan meluangkan waktu untuk belajar (A. Fauzi et al., 2019). Konsep pembelajaran tersebut sesuai dengan karakteristik dari pebelajar program Paket A yang berasal dari beragam usia, akses belajar dan waktu belajar yang dimiliki (A. Fauzi et al., 2019; Meliansari et al., 2017). Namun, dengan beragamnya karakteristik pebelajar maka kesiapan belajar merekapun akan berbeda yang berdampak pada hasil belajar. Hasil belajar peserta didik yang satu dengan peserta didik yang lain berbeda sesuai dengan tingkat kecerdasan, cara belajar maupun tingkat kemampuan belajar mandiri dari masing-masing individu (Meliansari et al., 2017). Hal senada diungkapkan bahwa dalam proses pembelajaran faktor internal dan eksternal memengaruhi hasil belajar (Saputro et al., 2019; Sondari et al., 2018). Faktor motivasi belajar peserta didik, minat, bakat serta tingkat kecerdasan termasuk dalam faktor internal. Sedangkan faktor eksternal yang berasal dari luar diri peserta didik seperti lingkungan belajar, sarana dan fasilitas, serta ketersediaan guru.

Pembelajaran mandiri mengutamakan pengamatan aktif secara mandiri. Perlu melibatkan pengaitan studi akademik dengan kehidupan sehari-hari dalam cara yang bermakna untuk mencapai tujuan yang berarti (Pamungkas, 2017). Kerja sama, sebagai bagian penting dari contextual teaching learning (CTL) memainkan peran penting dalam pembelajaran mandiri (Johnson, 2010). Fletcher (2016) menambahkan bahwa meskipun belajar mandiri berfokus pada diri pebelajar, namun pemahaman tentang diri dan praktik hanya dapat datang melalui interaksi dengan rekan kerja, peserta didik, teks, dan teman yang kritis. Pembelajaran mandiri yang didukung dengan komunitas praktik akan memberikan hasil yang lebih baik (Allen et al., 2016). Pembelajaran mandiri dalam program paket A dilakukan melalui kerjasama dengan kegiatan belajar masyarakat setempat dalam wadah PKBM.

Pusat Kegiatan Belajar Masyarakat (PKBM) diwujudkan secara terpadu dalam meningkatkan kondisi, sosial, ekonomi, dan budaya yang lebih bermanfaat. Selain itu, PKBM juga berperan sebagai wadah pemerataan pendidikan di İndonesia. PKBM merupakan prakarsa pembelajaran masyarakat yang didirikan dari, oleh, dan untuk masyarakat. PKBM adalah suatu institusi yang berbasis masyarakat (Community Based Institution) (Kementerian Pendidikan dan Kebudayaan, 2012). Pengembangan pendidikan masyarakat yang dilakukan oleh PKBM merupakan upaya peningkatan kemampuan personal orang dewasa sebagai anggota masyarakat.

Pelaksanaan pendidikan di PKBM berfungsi mewadahi masyarakat yang memerlukan pendidikan dan kemampuan belajar sepanjang hayat dalam rangka memupuk dan mengem- 


\section{JPPM (Jurnal Pendidikan dan Pemberdayaan Masyarakat), 7 (2), 2020 - 182}

Edhy Rustan, Baderia Baderia, Rahmat Tamrin

bangkan ketahanan fisik dan mentalnya (Majid, 2012). Lebih lanjut, Pamungkas (2017) mengatakan bahwa Program pembelajaran luar sekolah hendaknya disesuaikan dengan tujuan pembelajaran yang hendak dicapai. Olehnya itu, dengan menitikberatkan pada metode pembelajaran mandiri, program paket A tersebut terintegrasi dengan program keaksaraan, usaha mandiri, pengembangan budaya baca masyarakat, pemberdayaan perempuan, pendidikan keorangtuaan, dan penataan kelembagaan penyelenggara pendidikan masyarakat.

Kondisi Pandemic Covid-19 seperti saat ini, pembelajaran mandiri sangat vital untuk dimaksimalkan. Pembelajaran mandiri yang sebelumnya dilakukan bersamaan dengan pembelajaran tatap muka kini dialihkan ke pembelajaran mandiri dan pembelajaran daring. Kondisi tersebut tentu berdampak pada keefektivan proses pembelajaran. Berdasarkan uraian tersebut, perlu mengurai pembelajaran Self-study selama masa pandemic pada program paket A di Pusat Kegiatan Belajar Masyarakat (PKBM) Rantenase Kota Palopo pada fokus (1) bentuk pembelajaran Self-study pada program paket A di PKBM, (2) kendala yang dihadapi dalam pembelajaran self-study pada program paket A di PKBM, dan (3) manfaat pembelajaran self-study pada Program Paket A di Pusat Kegiatan Belajar Masyarakat (PKBM) Rantenase Kota Palopo.

\section{METODE}

Penelitian ini merupakan penelitian lapangan jenis deskriptif kualitatif (Sukmadinata, 2015). Penelitian ini dilakukan di Pusat Kegiatan Belajar Masyarakat (PKBM) Rantenase, Keluarahan Peta, Kecamatan Sandana, Kota Palopo. Sumber data, diperoleh dari warga belajar program paket A PKBM Rantenase. Subjek penelitian ini adalah pengelola, pendidik atau tutor, dan warga belajar program paket A atau program kesetaraan tingkat sekolah dasar. Karakteristik peserta didik adalah orang dewasa yang terlambat mengikuti pendidikan dasar.

Waktu penelitian pada saat pandemic Covid-19 bulan Maret sampai Juni. Teknik pengumpulan data berupa observasi, wawancara, dan dokumentasi. Analisis data dilakukan dengan menggunakan model Miles dan Huberman, yakni meliputi reduksi data, penyajian data, dan verifikasi/penarikan kesimpulan. Guna menguji kredibilitas data, peneliti kembali ke Pusat Kegiatan Belajar Masyarakat (PKBM) Kota Palopo untuk mengamati dan melakukan wawancara terhadap tutor dan peserta didik guna mendapatkan informasi lebih lengkap.

\section{HASIL DAN PEMBAHASAN}

\section{Bentuk Pembelajaran Self-study pada Program Paket A di PKBM}

Pembelajaran di Pusat Kegiatan Belajar Masyarakat (PKBM) Rantenase Kota Palopo dibagi menjadi tiga kegiatan terstruktur diantaranya: perencanaan, pelaksanaan, dan evaluasi.

\section{Perencanaan}

Pengelola menyusun dokumen perencanaan dengan mengacu pada model pembelajarannya out door (di luar ruangan) atau pembelajaran in door (di dalam ruangan) atau terpusat disuatu tempat, untuk menghasilkan proses pembelajaran berjalan dengan baik (dokumen perencanaan 2019). Berbeda di masa pandemi covid-19, pembelajaran semua diorientasikan di rumah masing-masing. Hal tersebut didukung oleh aturan yang berlaku yakni SE Mendikbud Nomor 4 Tahun 2020 tentang Pelaksanaan Pendidikan dalam Masa Darurat Coronavirus Disease (Covid-19) yang diperkuat dengan SE Sesjen Nomor 15 Tahun 2020 tentang Pedoman Pelaksanaan BDR selama darurat Covid-19.

Dokumen perencanaan sebagaimana yang dikemukakan, tertuang dalam bentuk silabus dan RPP dengan langkah-langkah pelibatan sumber belajar dari lingkungan dan bantuan masyarakat (Data Dokumentasi). Meski dikatakan demikian, namun dalam analisis dokumen perencanaan yang dilakukan, PKBM Rantenase belum mengintegrasikan Visi misi ke dalam kurikulum. Hal tersebut dibuktikan dengan belum dilakukannya (1) analisis kandungan KI-KD; (2) Analisis kebutuhan/keunggulan masyarakat/lokal yang perlu diadopsi dalam kurikulum; (3) 


\section{JPPM (Jurnal Pendidikan dan Pemberdayaan Masyarakat), 7 (2), 2020 - 183}

Edhy Rustan, Baderia Baderia, Rahmat Tamrin

Analisis Indikator; (4) Analisis kegiatan pembelajaran untuk mencapai KD; dan (5) Analisis penilaian untuk mengukur KD.

Materi belum dikembangkan sendiri pada satuan pendidikan, sehingga muatan kearifan lokal belum terwadahi dalam bahan ajar. Dari hasil analisis dokumen telah mengarah ke keterampilan, sosial-budaya sebagai pelajaran umum atau kurikulum nasional yang terdiri dari 12 mata pelajaran dari kementerian pendidikan. Belum terdapat adopsi materi Seni-budaya, Nilai-nilai tradisi, serta alam/lingkungan. Perlu pengembangan dengan mengacu pada potensi daerah, dengan melakukan FGD Bersama stakeholder yang terkait.

Berdasarkan telaah teks dokumen perencanaan, dalam silabus/RPP/perencanaan/kegiatan belajar yang direncanakan telah memuat metode, media sumber belajar, serta penilaian berbasis lingkungan, hanya saja sifatnya duplikasi dari sumber yang memiliki karakteristik berbeda dengan karakteristik daerah Palopo atau lingkungan sekitar. Sehingga dapat dikatakan pendekatan tidak CTL. Bahan ajar yang digunakan belum merujuk pada konteks lingkungan sekitar.

Pembelajaran yang dilakukan perlu disetting dengan learning community/masyarakat belajar. Berdasarkan hal itu, ahli dilibatkan atau diberi kesempatan dalam kegiatan pembelajaran. Pihak PKBM, memaknai indicator tersebut merupakan sosialisasi program kesetaraan yang menghadirkan tokoh masyarakat, sehingga konstribusi masyarakat terhadap kegiatan pembelajaran yang ada di PKBM atau Satuan PNF Sejenis.

\section{Pelaksanaan}

Pelaksanaan pembelajaran self-study sebelum dan saat pandemic di PKBM Rantenase diawali dengan pembagian modul dan ATK atau segala perlengkapan pembeljaran yang dapat menjadi acuan warga belajar dalam belajar mandiri sebagaimana yang diungkapkan SB (44 tahun).

Mengacu pada perencanaan yang telah ditetapkan, tempat pelaksanaan pembelajaran yang dipilih sebelum masa pandemic COVID-19 yakni di sekretariat, musollah, pelataran permandian Latuppa, dan di rumah warga. Tutor tidak memusatkan tempat pelaksanaan pembelajaran akan tetapi berpidah-pindah tempat agar warga belajar merasa enjoy, selain itu, juga bersilaturahmi dengan teman lainnya. Hal tersebut didukung hasil wawancara dengan JP (37 tahun) yang mengemukakan bahwa, pembelajaran sebelum pandemi dilakukan di berbagai tempat misalnya musholla, tempat wisata maupun rumah warga, tergantung kesepakatan tutor dan warga belajar

Sedangkan selama pandemic, pembelajaran dilaksanakan di rumah masing-masing warga belajar sebagaimana yang disampaikan oleh tutor JP (37 tahun) dalam wawancaranya yang mengatakan bahwa pertemuan tatap muka diganti dengan pembelajaran daring dan mandiri. Tutor berperan sebagai fasilitator menggunakan pesan whatsapp dan SMS. Hal senada diungkapkan oleh warga belajar WW (25 tahun) yang mengemukakan bahwa pembelajaran di kelas ditiadakan selama pandemic sudah dan untuk pemberian tugas serta arahan dari tutor disampaikan melalui pesan dan WA setiap pelajaran

Adapun proses pembelajaran program Paket A di PKBM Rantenase sebelum pandemic sangat berbeda dengan pembelajaran yang ada di Sekolah Dasar formal. Proses pembelajaran dibagi menjadi pembelajaran tatap muka dan pembelajaran mandiri. Pelaksanaan pembelajaran tatap muka hanya tiga kali (3x) dalam seminggu selebihnya dengan belajar mandiri. Hal ini dikerenakan lokasi pembelajaran yang sangat jauh dari masyarakat setempat khususnya di Kelurahan Peta Kecamatan Sendana. Agar warga dapat belajar mandiri, maka tutor yang ada di PKBM Rantenase memberikan buku paket panduan kepada warga belajar untuk dipelajari di rumah. Warga juga diberikan tugas individu dengan tujuan peserta didik dapat belajar mandiri, belajar bertanggung jawab pada diri sendiri dan memiliki insiatif yang tunggi untuk terus belajar (BJ, 41 tahun). Senada dengan hasil wawancara tersebut, JP (37 tahun) dalam wawancaranya mengatakan bahwa pembelajaran tatap muka sebelum pandei hanya dilakukan 3 kali seminggu dikarenakan jarak tempuh yang sangat jauh. 


\section{JPPM (Jurnal Pendidikan dan Pemberdayaan Masyarakat), 7 (2), 2020 - 184}

Edhy Rustan, Baderia Baderia, Rahmat Tamrin

Sementara proses pembelajaran saat pandemic hanya dilakukan dengan mengirim pesan sebagai petunjuk warga belajar untuk dapat belajar mandiri. Self-study selama masa pandemic sangat dimaksimalkan karena untuk melakukan proses belajar mengajar secara daring, warga belajar perlu menempuh jarak yang jauh demi mendapatkan akses jaringan. Kondisi demikian menjadi penyebab ketidaksesuaian kontrak belajar antar warga belajar dan tutor. Hasil penelusuran dokumen juga menunjukkan belum adanya kontrak belajar yang disusun tutor padahal semestinya kontrak belajar dibuat sebelum pembelajaran dimulai.

Sebagaimana program pembelajaran di PKBM lainnya, PKBM Rantenase juga mengintegrasikan pembelajaran mandiri sesuai dengan kebutuhan warga belajar. Warga belajar diajarkan tentang keaksaraan, usaha mandiri, pengembangan budaya baca masyarakat, pemberdayaan perempuan, pendidikan keorangtuaan, dan penataan kelembagaan penyelenggara pendidikan masyarakat. Hal tersebut senada dengan yang disampaikan BJ (41 tahun) bahwa warga belajar diajarkan membaca, menulis, bagaimana membuka usaha, dan berorganisasi. Pernyataan tersebut didukung oleh pernyataan yang diutarakan oleh warga belajar bahwa mereka diajarkan bagaimana menulis, membaca, mengelola hasil kebun, menjahit, sesuai dengan pengetahuan dan kebutuhan warga belajar (AA, 28 tahun).

Berdasarkan uraian tersebut diketahui bahwa proses pelaksanaan pembelajaran sebelum dan selama pandemic tidak terlalu jauh berbeda. Kontrak belajar dan materi pembelajaran tetap sama, hanya saja pembelajaran mandiri selama masa pandemi lebih dimaksimalkan dengan whatsapp group.

Evaluasi

Pada tahap selanjutnya tutor melaksanakan evaluasi pembelajaran Self-study pada program paket A di PKBM Rantenase Kota Palopo. Kegiatan evaluasi pembelajaran dilaksanakan sebagaimana evaluasi di pendidikan formal pada khususnya Sekolah Dasar (SD). Tiap tahunnya melaksanakan ujian semester mulai dari semester I, sampai semester II dan jadwal yang sama dengan kesetaraan paket A. Pelaksanaan evaluasi belajar ujian semester Program kesetaraan paket A senantiasa diawasi oleh pihak Dinas Pendidikan. Evaluasi yang dilakukan oleh tutor berkenan dengan proses yang berhubungan dengan pengumpulan informasi yang memungkinkan tutor menentukan tingkat kemajuan pembelajaran, ketercapaian tujuan pembelajaran, serta bagaimana berbuat baik pada waktu-waktu mendatang.

Sebelum pandemic evaluasi pembelajaran dilakukan dengan ujian tertulis dan praktik secara langsung dan serentak. Sedangkan saat pandemic, evaluasi dilakukan dalam bentuk tugas yang selanjutnya dikirimkan melalui pesan Whatsapp atau data dikumpul langsung di tutor. Hal ini sejalan dengan hasil wawancara yang dilakukan dengan warga belajar yang mengatakan bahwa meskipun pandemic, ujian semester tetap dilaksanaan. Hanya saja yang membedakan adalah ujian selama covid tidak dilakukan dikelas sebagaimana biasanya melainkan dengan mengumpulkan tugas (HA, 27 tahun).

Perbedaan mencolok antara sebelum pandemic dan selama pandemic dalam evaluasi terkait ujian kelulusan. Sebelum pandemic ujian kelulusan dilakukan melalui UAS dan UN sedangkan ujian kelulusan saat pandemic ditiadakan dan kelulusan peserta didik ditentukan oleh sekolah sebagaimana hasil wawancara dengan tutor BJ (41 tahun) yang mengatakan bahwa kelulusan peserta didik pada tahun ini ditentukan oleh sekolah berdasarkan nilai tugas yang dikumpulkan peserta didik setiap hari tanpa melaksanakan ujian nasional dan ujian akhir sekolah.

Untuk melakukan evaluasi tentu diperlukan pedoman dan kriteria penilaian, instrument dan soal-soal ujian. Dalam melakukan evaluasi para tutor mengacu pada pedoman dan kriteria penilaian baik sebelum maupun selama pandemic. Adapun hasil telusur dokumen evaluasi pembelajaran diperoleh bahwa dokumen terkait tersedia dengan lengkap.

Berdasarkan uraian tersebut dapat dikemukakan bahwa, bentuk pembelajaran Self-study pada program paket A di Pusat Kegiatan Belajar Masyarakat Rantenase (PKBM) Kota Palopo terdiri atas perencanaan, pelaksanaan, dan evaluasi. Perancanaan langkah-langkah pembelajar- 


\section{JPPM (Jurnal Pendidikan dan Pemberdayaan Masyarakat), 7 (2), 2020 - 185}

Edhy Rustan, Baderia Baderia, Rahmat Tamrin

an dilakukan agar proses pembelajaran dapat berjalan dengan lancar dan terarah sesuai apa yang diharapkan. Bentuk pembelajaran tersebut hampir sama pada saat sebelum pandemic dan selama pandemic berlangsung.

Pelaksanaan pembelajaran self-study yang dilaksanakan sesuai dengan yang dikemukakan oleh Fauzi et al. (2019) bahwa pembelajaran disesuaikan dengan kesempatan masing-masing peserta didik tanpa harus hadir di kelas secara langsung. Kemandirian dalam belajar perlu diberikan kepada warga belajar supaya mereka mempunyai tanggung jawab dalam mengatur dan mendisiplinkan dirinya dan dalam mengembangkan kemampuan belajar atas kemauan sendiri (Rusman, 2014).

\section{Kendala yang Dihadapi dalam Pembelajaran Self-study pada Program Paket A di PKBM Rantenase}

Kendala pembelajaran diartikan sebagai faktor yang menghambat pelakasanaan Program Paket A di PKBM sebelum pandemic covid-19 maupun selama pandemic berlangsung. Kendala yang terjadi dalam pembelajaran dapat dikategorikan ke dalam bentuk teknis maupun non teknis.

Kendala teknis biasanya disebabkan oleh kesulitan mengakses jaringan dan kurangnya sarana dan sumber belajar. Lokasi tempat tinggal warga belajar yang berada di pegunungan, jauh dari pusat kota meghadirkan kesulitan bagi peserta didik dalam mengakses internet maupun whatsapp group yang dijadikan sebagai bantuan belajar mandiri. Hal ini ditambah dengan minimnya sumber belajar yang digunakan karena hanya sebatas modul pembelajaran. Kesulitan mengakses lokasi pembelajaran juga berdampak pada ketersediaan sarana dan prasarana di lokasi. JP (37 tahun) menuturkan bahwa kurangnya prasarana memadai seperti media pembelajaran menyebabkan pembelajaran tatap muka kurang efektif. Pun dengan pembelajaran mandiri warga belajar terhambat akses internet sehingga modul menjadi sumber belajar utama warga.

Kendala teknis tersebut juga diungkapkan oleh warga belajar AA ( 28 tahun) bahwa warga belajar kesulitan mencari materi pelajaran yang bersumber dari intenet sebagaimana yang dilakukan di perkotaan. Warga belajar hanya mempelajari modul dan catatan saat pertemuan tatap muka.

Kendala teknis akses jaringan, ketersediaan sarana dan sumber belajar semakin terasa di masa pandemic. Hal ini dikarenakan pembelajaran dialihkan seluruhnya ke pembelajaran daring. Warga belajar yang hendak belajar mandiri kesulitan dalam mencari informasi pembelajaran dan materi pelajaran.

Selain kendala teknis, juga terdapat kendala non teknis dalam pembelajaran di PKBM. Kendala tersebut terkait dengan usia warga belajar dan jarak. Sebagian besar warga belajar telah menginjak usia kerja. Rata-rata peserta memiliki pekerjaan sehari-hari di kebun untuk menghidupi kebutuhan keluarganya. Sebagai akibat dari hal tersebut, jadwal pembelajaran di program paket A ada bertepatan dengan pekerjaannya masing-masing sehingga warga belajar tersebut banyak yang tidak hadir pada saat proses pembelajaran berlangsung. Waktu untuk belajar mandiri pun menjadi berkurang bahkan ada yang merasa sulit melakukan belajar mandiri karena selepas bekerja mereka beristirahat. Hal tersebut diungkapkan oleh warga belajar HM (30 tahun) bahwa membagi waktu untuk bisa belajar mandiri adalah hal yang sulit dilakukan karena setelah bekerja mereka kecapean dan hendak beristirahat. Senada dengan kendala tersebut, HA (27 tahun) juga mengatakan bahwa dirinya kadang melewatkan belajar mandiri dikarenakan sibuk bekerja.

Sedangkan di masa pandemic, pemberlakuan aturan pembatasan social memaksa warga untuk tetap berada di rumah atau membatasi aktivitas di rumah. Dengan kondisi tersebut warga belajar menghabiskan lebih banyak waktu di rumah sehingga waktu untuk belajar mandiri juga lebih banyak sebagaimana yang diungkapkan AA ( 28 tahun) bahwa waktu untuk belajar mandiri selama covid semakin banyak karena waktu untuk bekerja di luar sudah berkurang. 


\section{JPPM (Jurnal Pendidikan dan Pemberdayaan Masyarakat), 7 (2), 2020 - 186}

Edhy Rustan, Baderia Baderia, Rahmat Tamrin

Uraian tersebut menggambarkan bahwa tutor maupun warga belajar program paket A di Pusat Kegiatan Belajar Masyarakat (PKBM) Rantenase mempunyai banyak kendala serta kekurangan dan kelemahan dalam melaksanakan pembelajaran Self-study baik sebelum ada pandemic maupun selama pandemic. Hal ini sejalan dengan penelitian yang dilakukan oleh (Nofita, 2013) yang mengemukakan bahwa kesibukan warga belajar merupakan salah satu hambatan pada pembelajaran program paket A. Senada dengan hal tersebut, (Ciptasari \& Ustman, 2015) mengungkapkan bahwa yang menjadi kendala dalam pembelajaran program paket A adalah warga belajar itu sendiri. Hal ini dikarenakan pembelajaran mandiri mengutamakan pengamatan aktif secara mandiri (Pamungkas, 2017).

Adapun permasalahan akses internet, ketersediaan sarana dan sumber belajar yang menjadi permasalahan baik sebelum dan selama masa pandemic sejalan dengan penelitian I. Fauzi \& Sastra Khusuma (2020) yang menunjukkan bahwa permasalahan akses internet dan ketersediaan fasilitas belajar menjadi penghambat peserta didik dalam belajar di rumah selama pandemic covid-19. Selain akses yang sulit, pemahaman pembelajaran dalam menggunakan teknologi juga menjadi masalah belajar dari rumah (P. Putra et al., 2020). Dengan perkembangan teknologi yang semakin pesat di era 4.0 kebutuhan akan teknologi semakin meningkat namun adanya factor geografis dan permasalahan ekonomi menjadi penghalang bagi semua warga untuk dapat menggunakan internet (I. Fauzi \& Khusuma, 2020). Tidak hanya sebagai sumber informasi mengenai pembelajaran dari tutor, akses internet dalam pembelajaran self-study juga digunakan sebagai sumber belajar. Ketersediaan berbagai macam sumber belajar di internet sangat mendukung untuk warga belajar dapat belajar secara mandiri (I. Fauzi \& Khusuma, 2020). Olehnya itu, keterbatasan akses internet dan keterbatasan fasilitas belajar juga menjadi kendala utama dalam pembelajaran Self-study.

Meskipun demikian, warga belajar tetap semangat dalam mengikuti pembelajaran tatap muka maupun pembelajaran mandiri. Hasil wawancara dengan tutor BJ (41 tahun) yang mengemukakan bahwa warga belajar di PKBM Rantenase sangat bersemangat mengikuti pembelajaran meskipun dengan berbagai keterbatasan yang ada. Hal tersebut Nampak dari perkembangan kemampuan warga belajar yang semakin meningkat di setiap pertemuan. Pernyataan tersebut diperkuat dengan wawancara bersama warga belajar HA (27 tahun) yang menyampaikan bahwa kekurangan yang ditemui selama pembelajaran tidak menjadi penghalang warga belajar dalam menuntut ilmu apalagi para tutor selalu memberikan motivasi.

Dengan segala keterbatasan yang ada, warga belajar tetap berusaha agar mampu mengikuti proses belajar mengajar dan mencapai tujuan pembelajaran. Kaniati \& Kusmayadi (2013) mengemukakan bahwa salah satu factor yang berpengaruh terhadap pelaksanaan belajar mandiri adalah dari warga belajar namun dengan adanya dorongan psikologis maka kendala tersebut dapat diatasi. Dalam praktik pembelajaran self-study tutor berperan sebagai mediator antara materi pelajaran dan warga belajar. Tutor mendorong peserta didik untuk bertanggung jawab atas perkembangan diri mereka sendiri melalui kolaborasi, komunikasi dan refleksi. Pemberian motivasi merupakan salah satu kegiatan yang dilakukan dalam pembelajaran mandiri selain penyampaian dan pengaplikasian materi (Saripah \& Shantini, 2016). Agar peserta didik termotivasi mengikuti proses pembelajaran, tutor perlu meyakinkan peserta didik akan kemampuan yang dimiliki karena self-efficacy berpengaruh terhadap motivasi, afektif dan pemilihan kegiatan (Thaha \& Rustan, 2017). Self-efficacy didefenisikan sebagai keyakinan sejauh mana warga belajar mampu belajar mandiri.

\section{Manfaat Pembelajaran Self-study pada Program Paket A di PKBM Rantenase Kota Palopo}

Manfaat program pembelajaran dapat dilihat dari aspek lulusan dan aspek kebermanfaatan pembelajaran. Tinjauan aspek lulusan pada peserta program A yang diselenggarakan PKBM Rantenase, diperoleh data tentang lulusan seperti jumlah alumni dua tahun terakhir. Meski demikian tidak diperoleh data pemanfaatan sebagai wujud outcome yang berupa 


\section{JPPM (Jurnal Pendidikan dan Pemberdayaan Masyarakat), 7 (2), 2020 - 187}

Edhy Rustan, Baderia Baderia, Rahmat Tamrin

dokumen (foto, sertifikat, karya, dan lainnya). Data tentang pelacakan alumni yang menelusuri lama tunggu alumni dalam memeroleh pekerjaan juga belum ada. Hasil wawancara dengan kepala sekolah diperoleh bahwa semua peserta didik yang mengikuti ujian nasional selama dua tahun terakhir berhasil lulus dengan nilai yang cukup memuaskan.

Aspek lainnya adalah kebermanfaatan pengalaman belajar peserta didik. Pada umumnya, warga belajar pada program paket A di PKBM tidak tau membaca dan menulis. Meskipun usianya dewasa, namun baru mengenyam pendidikan dasar. Oleh sebab itu, masyarakat Rantenase Kelurahan Peta sangat tertinggal akan pendidikan. Namun, dengan adanya pembelajaran Selfstudy pada program paket A yang dilaksanakan di PKBM Rantenase Kota Palopo warga belajar secara bertahap sudah mengetahui membaca dan menulis. Hal tersebut sejalan dengan yang diungkapkan HA (27 tahun) bahwa setelah mengikuti pembelajaran mandiri di PKBM Rantenase, dirinya kini mulai mampu membaca dan menulis. Hal senada diungkapkan oleh IW (34 tahun) yang mengatakan bahwa kehadiran program paket A khususnya di Kelurahan Peta membantu masyarakat mengejar ketertinggalan dalam dunia pendidikan yang ditandai dengan kemampuan masyarakat membaca dan menulis.

Selain kemampuan menulis dan membaca, pembelajaran program paket A juga memberikan manfaat yakni warga belajar dibekali keterampilan dalam berwirausaha. Hal tersebut disampaikan oleh JN (31 tahun) bahwa, selama belajar di PKBM mereka diajarkan membaca, menulis dan keterampilan berwirausaha dalam mengelolah hasil tani agar memiliki nilai jual di masyarakat. Pernyataan yang sama juga disampaikan oleh tutor BJ (41 tahun) yakni telah banyak alumni yang bekerja di perusahaan seperti Panfli, Alfamidi dan perusahaan di Morowali.

Berdasarkan beberapa hasil wawancara tersebut dengan warga belajar, maka penulis dapat mengambil satu kesimpulan bahwa meskipun terdapat beberapa kendala yang ditemui selama proses pembelajaran self-study namun proses pembelajaran tetap dapat berjalan dan memberikan manfaat kepada warga belajar sebagaimana yang diharapkan. Hasil tersebut sejalan dengan penelitian yang dilakukan oleh Putra et al. (2017) bahwa melalui pembelajaran mandiri hasil belajar warga belajar di PKBM dapat ditingkatkan.

Pembelajaran self-study merupakan kegiatan pembelajaran dari pengalaman sendiri yang kemudian di evaluasi untuk mendapatkan pengalaman baru (Craig, 2008). Agar lebih efektif pembelajaran self-study dilakukan secara berkelompok (Vanassche \& Kelchtermans, 2015). Menurut teori naturalisme romantik dari Jean Jacques Rousseau individu memiliki potensipotensi atau kemampuan-kemampuan yang masih terpendam dan memiliki kekuatan sendiri untuk mengembangkan dirinya secara mandiri (Rusman, 2014).

Pencapaian peningkatan kemampuan membaca dan menulis serta keterampilan dan berwirausaha merupakan pengetahuan yang diperlukan oleh warga belajar PKBM Rantenase Palopo. Hal ini sesuai dengan yang diungkapkan Pamungkas (2017) bahwa Program pembelajaran luar sekolah hendaknya dilaksanakan sesuai dengan kebutuhan warga belajar. Lebih lanjut diungkapkan oleh Salman dan Tohani (2019) bahwa pembelajaran di PKBM mampu menghasilkan lulusan yang memiliki kepercayaan diri, kedisiplinan, kemampuan dan keterampilan untuk dapat digunakan dalam dunia kerja.

Di masa pandemi, kebermanfaatan pembelajaran self-study nampak dalam peningkatan literasi fungsional terutama kemampuan literasi digital. Hal ini sebagaimana diungkapkan oleh warga belajar bahwa selama pembelajaran self-study mereka dituntut untuk mampu memanfaatkan teknologi meskipun dengan akses jaringan yang tidak memadai. Kondisi ini membangkitkan semangat penggerak dalam pemberdayaan masyarakat terutama dalam pembelajaran meski dengan segala keterbatasan. Hasil penelitian ini sejalan dengan penelitian (Rustan et al., 2019) bahwa dalam pembelajaran berbasis online secara tidak langsung pembelajar akan diakrabkan dengan teknologi. Interaksi yang diciptakan oleh pembelajaran online telah menimbulkan perasaan sensitif terhadap penggunaan teknis perangkat lunak, fitur, dan aplikasi. Selain itu, interaksi ini melahirkan kemandirian dan disiplin. Kemandirian yang dihasilkan sejalan dengan metode pembelajaran self-study yang diterapkan. Dengan demikian peserta didik memperoleh pengalaman belajar yang bermakna berdasarkan potensi dan kebutuhannya. 


\section{SIMPULAN}

Pembelajaran self-study di PKBM Rantenase Palopo dilaksanakan melalui tiga tahapan yakni (1) perencanaan yang tertuang dalam RPP sesuai dengan analisis kondisi dan kebutuhan warga belajar, (2) pelaksanaan dengan pembagian modul sebagai sumber belajar utama dan bimbingan dari tutor selama belajar mandiri, dan (3) evaluasi melalui ulangan semester maupun ujian akhir. Pembelajaran sebelum dan selama pandemi tidak jauh berbeda hanya saja selama pandemic pembelajaran mandiri dimaksimalkan di rumah masing-masing dengan bantuan tutor mengarahkan peserta didik melalui pesan SMS maupun Whatsapp sedangkan evaluasi diganti dengan penugasan. Dalam penerapan pembelajaran mandiri ditemui beberapa kendala baik kendala teknis maupun non teknis. Selama pandemic kendala teknis menjadi kendala paling dominan diantaranya kesulitan mengakses internet, ketersediaan sarana dan prasarana serta sumber belajar. Kendala non teknis yakni usia warga belajar yang sebagian besar sudah dalam usia kerja namun tidak begitu berpengaruh selama pandemi.

Penerapan pembelajaran self-study mampu memberikan manfaat kepada warga belajar dalam literasi fungsional terutama kemampuan literasi digital, membangkitkan semangat penggerak dalam pemberdayaan masyarakat terutama dalam pembelajaran, meski dengan segala keterbatasan. Peserta didik memperoleh pengalaman belajar yang bermakna berdasarkan potensi dan kebutuhannya.

\section{DAFTAR PUSTAKA}

Allen, J., Park Rogers, M., \& Borowski, R. (2016). "I am out of my comfort zone": Self-study of the struggle of adapting to the professional identity of a teacher educator. Studying Teacher Education, 12(3), 320-332. https://doi.org/10.1080/17425964.2016.1228048

Ciptasari, D. R., \& Ustman. (2015). Manajemen program pendidikan kesetaraan Kejar Paket C "Harapan Bangsa" di UPTD SKB Ungaran Kabupaten Semarang. Journal of Nonformal Education and Community Empowerment, 4(2), 115-120. https://journal.unnes.ac.id/sju/index.php/jnfc/article/view/8048

Craig, C. J. (2008). Joseph Schwab, self-study of teaching and teacher education practices proponent? A personal perspective. Teaching and Teacher Education, 24(8), 1993-2001. https://doi.org/10.1016/j.tate.2008.05.008

Fauzi, A., Siregar, H., \& Meilya, I. R. (2019). Penerapan model pembelajaran project based learning dalam pembelajaran mandiri pada pendidikan kesetaraan Paket C. Journal of Nonformal Education and Community Empowerment, 3(1), 52-58. https://doi.org/10.15294/pls.v3i1.30871

Fauzi, I., \& Khusuma, I. H. S. (2020). Teachers' elementary school in online learning of COVID19 pandemic conditions. Jurnal Iqra': Kajian Ilmu Pendidikan, 5(1), 58-70. https://doi.org/10.25217/ji.v5i1.914

Fletcher, T. (2016). Developing principles of physical education teacher education practice through self-study. Physical Education and Sport Pedagogy, 21(4), 347-365. https://doi.org/10.1080/17408989.2014.990370

Johnson, E. B. (2010). Contextual Teaching and Learning. Kaifa Learning.

Kaniati, R., \& Kusmayadi, D. (2013). Upaya tutor dalam menerapkan pendekatan pembelajaran mandiri pada warga belajar Paket C di PKBM Pelita Pratama Bandung. EMPOWERMENT: Jurnal Ilmiah Program Studi Pendidikan Luar Sekolah, 2(2), 1-12. https://doi.org/10.2246o/empowerment.v2i2p1-12.593

Kementerian Pendidikan dan Kebudayaan. (2012). Standar dan prosedur penyelenggaraan pusat kegiatan belajar masyarakat (PKBM). Direktorat Pembinaan Pendidikan Masyarakat Direktorat Jenderal Pendidikan Anak Usia Dini Nonformal dan Informal.

Majid, A. (2012). Belajar dan pembelajaran pendidikan Agama Islam. Rosdakarya. 


\section{JPPM (Jurnal Pendidikan dan Pemberdayaan Masyarakat), 7 (2), 2020 - 189}

Edhy Rustan, Baderia Baderia, Rahmat Tamrin

Meliansari, Hasyim, A., \& Yanzi, H. (2017). Hubungan Kemampuan Belajar Mandiri dengan Hasil Belajar Mata Pelajaran PPKn Di Paket C. 13(3), 1576-1580.

Nofita, N. A. (2013). Hambatan - hambatan warga belajar dalam proses pembelajaran program Paket C di Kecamatan Pancung soal Kabupaten Pesisir Selatan. Spektrum: Jurnal Pendidikan Luar Sekolah (PLS), 1(1), 144. https://doi.org/10.24036/spektrumpls.vii1.1489

Pamungkas, A. H. (2017). Rancangan pengembangan program pendidikan kewirausahaan berbasis pendidikan luar sekolah. Seminar Nasional Pendidikan Nonformal FKIP Universitas Bengkulu, 1(1), 199-206.

Putra, P., Liriwati, F. Y., Tahrim, T., Syafrudin, S., \& Aslan, A. (2020). The students learning from home experiences during Covid-19 school closures policy in Indonesia. Jurnal Iqra': Kajian Ilmu Pendidikan, 5(2), 30-42. https://doi.org/10.25217/ji.v5i2.1019

Putra, R. A., Kamil, M., \& Pramudia, J. R. (2017). Penerapan metode pembelajaran mandiri dalam meningkatan hasil belajar peserta didik. Jurnal Pendidikan Luar Sekolah, 13(1), 2336.

Rusman. (2014). Model-model pembelajaran mengembangkan profesionalisme guru (2nd ed.). Raja Grafindo Persada.

Rustan, E., Hasanuddin, M. I., \& Ajiegoena, A. M. (2019). Social sensitivity in the interaction of the online teaching-learning profession community in Indonesia. Hicospos 2019: Social and Climate Change in 5.o Society.

Salman, M. A., \& Tohani, E. (2019). Pemberdayaan masyarakat kawasan industri pertambangan melalui penyelenggaraan program paket $C$ Community empowerment of mining industry areas through certification of package C programs. JPPM (Jurnal Pendidikan Dan Pemberdayaan Masyarakat), 6(2), 100-110.

Saputro, D. A., Wijaya, A. T. H., \& Ariefianto, L. (2019). Peran profesionalisme tutor dalam meningkatan motivasi belara pada warga belajar Paket C di PKBM Al-Muttaqin Desa Banjarsengon Kecamatan Patrang Kabupaten Jember. LEARNING COMMUNITY Jurnal Pendidikan Luar Sekolah, 3(2), 70-73.

Saripah, I., \& Shantini, Y. (2016). Implementasi model pembelajaran mandiri program pendidikan kecakapan hidup perempuan. JPPM (Jurnal Pendidikan Dan Pemberdayaan Masyarakat), 3(2), 176. https://doi.org/10.21831/jppm.v3i2.11545

Sondari, Y., Hamdani, D. I. A., \& Nurhayati, S. (2018). Penerapan pendidikan inklusif pada program kesetaraan di PKBM Srikandi. Jurnal Comm-Edu, 1(20), 127-137.

https://doi.org/dx.doi.org/10.2246o/comm-edu.vii2.639

Sukmadinata, N. S. (2015). Metode penelitian pendidikan. PT Remaja Rosdakarya.

Thaha, H., \& Rustan, E. (2017). Orientasi religiusitas dan efikasi diri dalam hubungannya dengan kebermaknaan pendidikan Agama Islam pada Mahasiswa IAIN Palopo. Jurnal Studi Agama Dan Masyarakat, 13(2), 163-179. https://doi.org/10.23971/jsam.v13i2.551

Vanassche, E., \& Kelchtermans, G. (2015). The state of the art in self-study of teacher education practices : a systematic literature review. Journal of Curriculum Studies, 47(4), 508-528. https://doi.org/10.1080/00220272.2014.995712 